\title{
A MEASUREMENT OF ROUGHNESS AS INDICATOR OF ROAD NETWORK CONDITION - CASE STUDY SERBIA
}

\author{
Nebojša Radović, Igor Jokanović, Bojan Matić, Miloš Šešlija
}

Preliminary note

Earlier researches have established that the measurement of pavement longitudinal roughness expressed through International Roughness Index (IRI) is one of the most important indicators for overall evaluation of road network condition. At the same time IRI presents the key trigger for planning and applying the different road maintenance works like pavement rehabilitation or reconstruction. This paper examines the existing methods for measurement of pavement roughness and evaluation of the road network condition in the Republic of Serbia in total length of $13191,34 \mathrm{~km}$.

Keywords: condition, pavement, road network, roughness

Mjerenje hrapavosti kolnika kao indikator stanja cestovne mreže - studija slučaja Srbija

Prethodno priopćenje Prethodna istraživanja su utvrdila da je mjerenje uzdužne hrapavosti kolnika izraženo kroz međunarodni indeks hrapavosti (International Roughness Index - IRI) jedan od najvažnijih pokazatelja za ukupnu ocjenu stanja cestovne mreže. U isto vrijeme IRI predstavlja ključni okidač za planiranje i primjenu različitih radova održavanja cesta kao što su sanacije ili rekonstrukcije kolnika. $U$ radu se razmatraju postojeće metode za mjerenje hrapavosti kolnika $i$ ocjenu stanja cestovne mreže u Republici Srbiji u ukupnoj dužini od 13 191,34 km.

Ključne riječi: cestovna mreža, kolnik, hrapavost, stanje

\section{Introduction}

Pavement surface roughness is generally defined as an expression of irregularities in the pavement surface that adversely affect the ride quality of a vehicle (and thus the user). Roughness is an important pavement characteristic because it affects not only ride quality but also vehicle delay costs, fuel consumption and road maintenance costs.

Pavement surface roughness is represented through longitudinal profiles of the road surfaces, taken along the imaginary line. Longitudinal profiles show the design grade, roughness and texture [1] (Fig. 1).

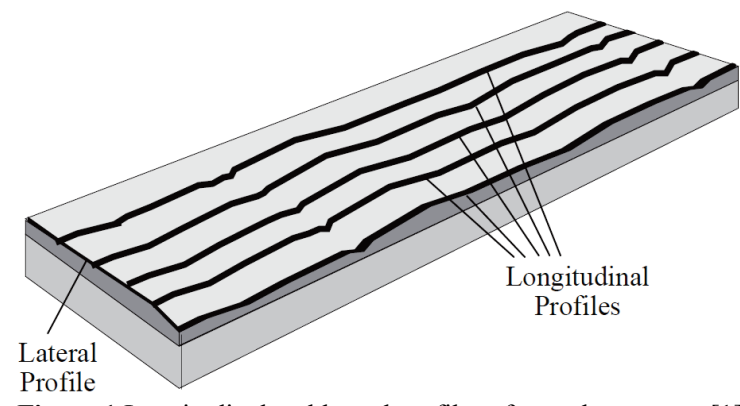

Figure 1 Longitudinal and lateral profiles of a road pavement [1]

Pavement surface roughness has primary importance for traffic safety and comfort. Pavement surface roughness represents road profile deformation which highly affects road users. It develops through permanent material deformation in some or all pavement layers, progressively from the moment of road construction.

Development degree of this type of pavement distress accelerates with pavement weakening due to initiation of distresses such as cracking, ravelling, potholes, edge breaks, deformations, etc.
Pavement surface roughness considerably affects dynamic vehicle motion, wearing of pneumatics and, therefore, road user costs.

Earlier researches $[1,2,3]$ have established that the measurement of pavement longitudinal roughness expressed through International Roughness Index (IRI) is one of the most important indicators for overall evaluation of road network condition. At the same time IRI presents the key trigger for planning and applying the different road maintenance works like pavement rehabilitation or reconstruction.

Road maintenance works and activities can be divided into the following categories:

- Routine (regular) maintenance

- Preventive maintenance

- Periodic maintenance

- Rehabilitation

- Reconstruction

- Emergency maintenance.

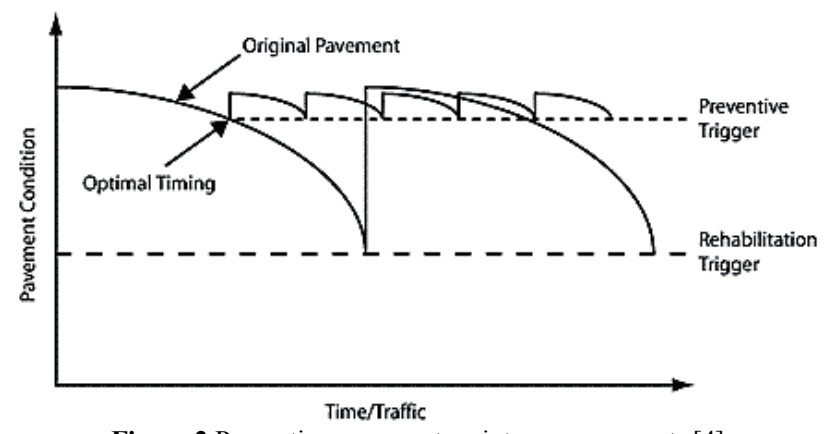

Figure 2 Preventive pavement maintenance concepts [4]

For the purposes of effective road maintenance management it is necessary to have the updated road information system as well as adequate decision model. Model for the analysis of investment in the development and management of roads HDM-4 (Highway Development and Management Model) [5] is a complex software tool for 
technical - economic evaluation of road projects and analysis of investments in the works on the road network, widely accepted by the International Financial Institutions (IFIs) [6].

Fig. 2 illustrates how road condition deteriorates with time and how road life may be extended by the appropriate actions on road maintenance achieving significant savings for the society. Pavement condition is usually expressed through various Quality / Key Performance Indicators (QIs/KPIs), e.g. International Roughness Index (IRI), Present Serviceability Index (PSI) or Pavement Condition Index (PCI).

The paper examines the existing pavement quality measurement methods, as well as deterioration and prediction models for pavement roughness and their use for the effective evaluation of the overall road network condition in the Republic of Serbia, with the total length of $13191,34 \mathrm{~km}$.

\section{State of the art}

The IRI was first presented by the World Bank in Technical Paper Number 46, which suggested grouping various measuring methods into four classes, based on the ability of equipment providing precise IRI measurement and calculation results [3].

Later, ASTM (American Society for Testing and Materials) developed the ASTM E 950-94 standard, which classified roughness measuring devices into four classes according to their accuracy and methodology used in IRI evaluations:

- Class I: incorporate precision profiles,

- Class II: consider other profile methods,

- Class III: use IRI estimates from correlation equations, and

- Class IV: consider subjective ratings and uncalibrated measures.

Tab. 1 gives examples of the types of equipment in the different classes.

Table 1 Examples of Roughness Measuring Equipment [7]

\begin{tabular}{|l|l|}
\hline \multicolumn{1}{|c|}{ Class } & \multicolumn{1}{c|}{ Equipment } \\
Class I & $\begin{array}{l}\text { Laser profiles: Non-contact } \\
\text { lightweight profiling devices } \\
\text { and portable laser profilers } \\
\text { Manually operated devices: } \\
\text { e.g. TRL beam, Face } \\
\text { Dipstick/ROMDAS Z-250, } \\
\text { ARRB Walking Profiler }\end{array}$ \\
\hline $\begin{array}{l}\text { Class II } \\
\text { Other profilometer methods }\end{array}$ & $\begin{array}{l}\text { APL profilometer, } \\
\text { profilographs (e.g., } \\
\text { California, Rainhart), optical } \\
\text { profilers, and } \\
\text { inertial profilers (GMR) }\end{array}$ \\
\hline $\begin{array}{l}\text { Class III } \\
\text { IRI estimates from correlation } \\
\text { equations }\end{array}$ & $\begin{array}{l}\text { Roadmaster, ROMDAS, } \\
\text { Roughometer, TRL } \\
\text { Bump Integrator, rolling } \\
\text { straightedge. }\end{array}$ \\
\hline $\begin{array}{l}\text { Class IV } \\
\text { Subjective } \\
\text { ratings/uncalibrated measures }\end{array}$ & $\begin{array}{l}\text { Key code rating systems, } \\
\text { visual inspection, } \\
\text { ride over section }\end{array}$ \\
\hline
\end{tabular}

To provide a common quantitative basis on which the different measures of roughness can be compared, the
International Roughness Index (IRI) was developed by World Bank. The IRI summarizes the longitudinal pavement surface profile in the wheel path and is computed from pavement surface elevation data collected by either topographic survey or a mechanical profilometer or a dipstick. IRI is reported in units of $\mathrm{m} / \mathrm{km}$.

The standardized IRI values $(\mathrm{m} / \mathrm{km})$ are [8]: $0,5 \div 2,0$ for airport runways and super highways,

$1,5 \div 3,5$ for new pavement

$2,5 \div 5,5$ for older pavement,

$4,0 \div 11,0$ for damaged pavement and

$8,0 \div 20,0$ for rough unpaved roads.

\section{Experimental part \\ 3.1 Instrumentation}

The pavement roughness measurement on 13 191,34 $\mathrm{km}$ of road network of Serbia was done by the portable laser profilers installed on the ARAN (Automatic Road ANalyzer) multifunctional vehicle for road network data collection.

Equipment is based on contact-free scanning of the values of vertical acceleration of the measuring axle's unsprung mass and the values of vertical acceleration of the sprung mass of the vehicle's body (Fig. 3).

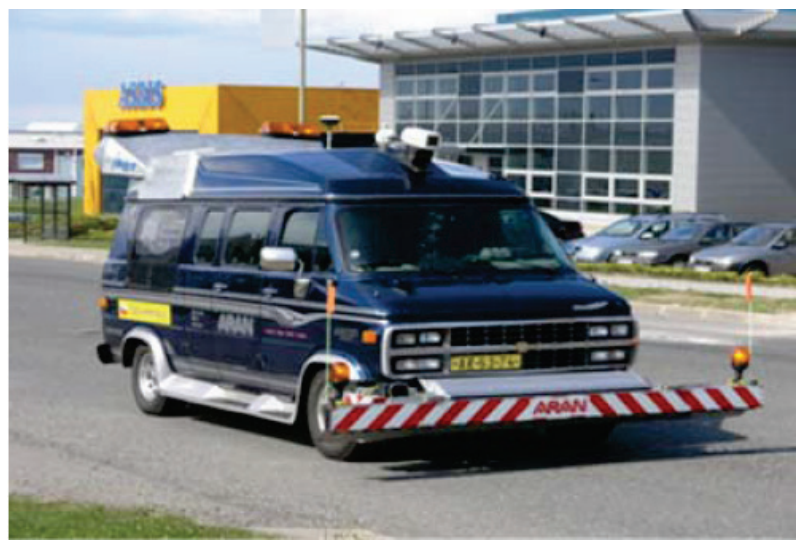

Figure 3 Automatic Road Analyzer (ARAN) [9]

ARAN uses state-of-the-art technology for scanning values required to calculate the IRI by a commonly used model known as a quarter-vehicle, defined by internationally-accepted studies [3].

This method is based on a simulation of a "quartervehicle" through computation from the values measured by a laser camera. It is called comparative "vertical plane", generated by the optics system of a camera. This system is rigidly mounted on the mass of the vehicle's body, generating a longitudinal road profile at $50 \mathrm{~mm}$ intervals, detecting wavelengths from $100 \mathrm{~mm}$ to $100 \mathrm{~m}$, approaching the so called "true profile" from the values obtained from an accelerometer. Accelerometer installed on this camera, measures gravitational accelerations of the vehicle's mass in interaction with the road's longitudinal irregularities.

The readings obtained from the profile and acceleration measurements are pre-processed by the designated subsystem's control computer and sent to the central board computer, which in real time computes the IRI index, which the operator sitting in the vehicle can 
observe. All values are stored on storage media for further processing in office workstations.

Positions of all measurement readings are digitally and visually identified according to the client-defined methodology, both in linear as well as nodal systems.

\subsection{Measurement accuracy and speed}

The accuracy of the used accelerometer is $\pm 1 \mathrm{mG}$, and that of the $16 \mathrm{kHz}$ laser camera $\pm 0,2 \mathrm{~mm}$. The measurement speed can be variable, ranging from 25 to $90 \mathrm{~km} / \mathrm{h}$.

\subsection{Sampling frequency}

The sampling step is $50 \mathrm{~mm}$, which allows the system to pick up wavelengths from $100 \mathrm{~mm}$ to $100 \mathrm{~m}$. The IRI values are then determined as an average value of the profile, adjustable from 10,2 $\mathrm{m}$ upwards.

\section{Pavement roughness development model}

Road environment factors (non-structural factors) affect pavement surface evenness primarily through air temperature and precipitation. These factors are not directly related with traffic volume or pavement bearing capacity, but they essentially affect development of pavement roughness and it is very hard to quantify them.

It can be expected that pavement quality, age and initial pavement surface roughness have dominant effect on development of pavement surface roughness.

Climate characteristics like temperature and air humidity also have effect, because with increase of temperature the oxidation of bituminous binder in pavement asphalt layers also increases, with simultaneous decrease of rigidness.
Modelling of pavement roughness development simultaneously comprises effects of different pavement distress types and relative effects of traffic volume, pavement strength, pavement structure type, pavement age and ambiental characteristics.

Pavement roughness development model is expressed with the following equation in the HDM-4 model [11]:

$\Delta \mathrm{RI}=\mathrm{Kgp}+\Delta \mathrm{RIs}+\Delta \mathrm{RIc}+\Delta \mathrm{RIr}+\Delta \mathrm{RIt}+\Delta \mathrm{RIe}$

where:

Kgp - calibration factor of general surface roughness development,

$\Delta \mathrm{RI}$ - gradual increase of pavement surface roughness,

Kgm - development calibration factor for environmental component.

Factors representing gradual increase of pavement surface roughhess due to:

- $\quad \Delta$ RIs - structural pavement deterioration

- $\quad \Delta$ RIc - cracking,

- $\quad \Delta$ RIr - rutting,

- $\quad \Delta$ RIt - potholes,

- $\quad \Delta$ RIe - climate effects.

\section{Results and discussion}

The pavement roughness data on the $13191,34 \mathrm{~km}$ of the main and regional road network were collected during the period of three consecutive years $(2008 \div 2010)$ with multifunctional vehicle ARAN.

Pavement surface roughness data are statistically processed, analysed and presented by functional class of road network indicated overall pavement condition of road network. Tab. 2 and Fig. 4 summarize the obtained results.

Table 2Road network condition by road class [12]

\begin{tabular}{|c|c|c|}
\hline Road network class & Length of road network $(\mathrm{km})$ & $\%$ \\
\hline \multicolumn{3}{|l|}{ Motorways and semimotorways } \\
\hline Good condition $\mathrm{IRI} \leq 3 \mathrm{~m} / \mathrm{km}$ & 943,28 & 88,80 \\
\hline Fair condition $3<\mathrm{IRI} \leq 5 \mathrm{~m} / \mathrm{km}$ & 118,92 & 11,20 \\
\hline Poor condition $5<\mathrm{IRI} \leq 8 \mathrm{~m} / \mathrm{km}$ & 0,00 & 0,00 \\
\hline Very poor condition IRI $>8 \mathrm{~m} / \mathrm{km}$ & 0,00 & 0,00 \\
\hline Total: & 1062,20 & 100,00 \\
\hline \multicolumn{3}{|l|}{ Main road network } \\
\hline Good condition $\mathrm{IRI} \leq 3 \mathrm{~m} / \mathrm{km}$ & 1327,43 & 32,92 \\
\hline Fair condition $3<\mathrm{IRI} \leq 5 \mathrm{~m} / \mathrm{km}$ & 1743,66 & 43,24 \\
\hline Poor condition $5<\mathrm{IRI} \leq 8 \mathrm{~m} / \mathrm{km}$ & 863,95 & 21,42 \\
\hline Very poor condition IRI $>8 \mathrm{~m} / \mathrm{km}$ & 97,71 & 2,42 \\
\hline Total: & 4032,74 & 100,00 \\
\hline \multicolumn{3}{|l|}{ Regional road network } \\
\hline Good condition $\mathrm{IRI} \leq 3 \mathrm{~m} / \mathrm{km}$ & 669,75 & 8,27 \\
\hline Fair condition $3<\mathrm{IRI} \leq 5 \mathrm{~m} / \mathrm{km}$ & 2952,56 & 36,47 \\
\hline Poor condition $5<\mathrm{IRI} \leq 8 \mathrm{~m} / \mathrm{km}$ & 3399,87 & 41,99 \\
\hline Very poor condition IRI $>8 \mathrm{~m} / \mathrm{km}$ & 1074,22 & 13,27 \\
\hline Total: & 8096,40 & 100,00 \\
\hline \multicolumn{3}{|l|}{ Total all networks } \\
\hline Good $\mathrm{IRI} \leq 3 \mathrm{~m} / \mathrm{km}$ & 2940,46 & 22,29 \\
\hline Fair $3<\mathrm{IRI} \leq 5 \mathrm{~m} / \mathrm{km}$ & 4815,14 & 36,50 \\
\hline Poor $5<\mathrm{IRI} \leq 8 \mathrm{~m} / \mathrm{km}$ & 4263,82 & 32,32 \\
\hline Very poor IRI $>8 \mathrm{~m} / \mathrm{km}$ & 1171,92 & 8,88 \\
\hline Total: & 13191,34 & 100,00 \\
\hline
\end{tabular}


Measured pavement surface roughness data are weighted by section length independently from road class.

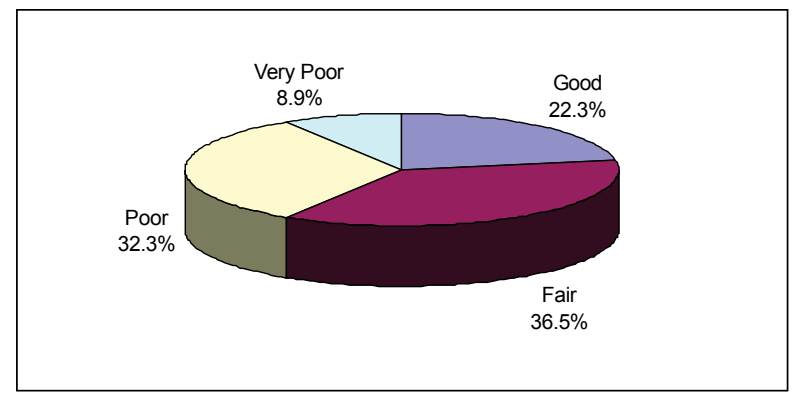

Figure 4 Overall road network condition (2010)

\section{Conclusion}

This paper examines the existing methods for measurement and model for prediction of pavement surface roughness and evaluation of the road network condition in the Republic of Serbia in total length of $13191,34 \mathrm{~km}$

Pavement surface roughness is an important measurement of a road's health. Roughness and its associated IRI index are commonly used around the world, thus providing a standard platform for comparison of road networks. With the increase of pavement roughness, its deterioration further accelerates, in a nonlinear manner, due to the vicious circle forming between the mutually exacerbated roughness and the increase of dynamic vehicles/pavement interaction forces.

Based on the measurements and analyses of pavement surface roughness data on the road network of the Republic of Serbia, it can be concluded that over $40 \%$ of the total road network is in poor or very poor condition. It also can be concluded that such road network condition requires immediate significant road investments in the road network to prevent further development of the road pavement surface roughness and deterioration of the road network.

\section{Acknowledgements}

The research presented in this paper was conducted with the support of the PE "Roads of Serbia" using the data from the Road Data Base (RDB). The paper also presents a part of the research projects TR 36017, funded by the Ministry of Science and Technological Development of Serbia, as well as research project "Development and Application of Contemporary Procedures for Design, Construction and Maintenance of Buildings" supported by Department for Civil Engineering and Geodesy of Faculty of Technical Sciences, Novi Sad. The authors extend their thanks to all authorities that approved the use of the data for their kind assistance and understanding.

\section{References}

[1] Sayers, M. W.; Karamihas, S. M. The Little Book of Profiling. / Basic Information about Measuring and Interpreting Road Profiles, (1998).

[2] Sayers, M. W.; Gillespie, T. D.; Queiroz, Q. The International Road Roughness Experiment: Establishing
Correlation and a Calibration Standard for Measurements, World Bank Technical Paper No. 45, The World Bank, Washington DC, (1986).

[3] Sayers, M. W.; Gillespie, T. D.; Paterson,W. D. Guidelines for the Conduct and Calibration of Road Roughness Measurements, World Bank Technical Paper No. 46, The World Bank, Washington DC, (1986).

[4] Principles of Pavement Preservation, http://www.fhwa.dot.gov (access date: 05.10.2014).

[5] ISOHDM Technical Secretariat the University of Birmingam, Highway Development \& Management HDM4, Volume 1-7 (2000).

[6] Radović, N.; Šešlija, M.; Peško, I. Expert Project Analyses in the Process of Road Maintenance Management. // Gradjevinar. 65, 7(2013) pp 641-652.

[7] Bennet, C. R.; Chamorro, A.; Chen, C.; Solminihac, H.; Flintisch, G. W. Data Collection Technologies for Road Management, The World Bank Washington, D.C., 2007.

[8] Kertesz, I.; Lovas, T.; Barsi, A. Photogrammetric Pavement Detection System. // XXI ${ }^{\text {st }}$ International Society for Photogrammetry and Remote Sensing (ISPRS) Congress, Beijing China. (2008), pp. 897-902.

[9] JV CPV-NIEVELT, Road Data Base - Final Report, PE "Roads of Serbia", Belgrade, 2010.

[10] First International-Brazilian Experiment, Technical Regulations of the World Bank No. 46, PIARC International Experiment (1998).

[11] Odoki, J. B.; Kerali, H. G. R. Analytical Framework and Model Descriptions. // HDM-4 Documentation. Volume Four, (2000).

[12] Radović, N. Preparation of Program Analyses of State Road Network and Transport Rehabilitation Project Performance Indicators - Final report, PE "Roads of Serbia", Belgrade, 2011.

\section{Authors' addresses}

Nebojša Radović, PhD, Assoc. Prof. (corresponding author) University of Novi Sad,

Faculty of Technical Sciences, Trg Dositeja Obradovića 6, 21000 Novi Sad, Serbia E-mail: radovicn@drenik.net

Igor Jokanović, PhD, Assist. Prof.

University of Novi Sad, Faculty of Civil Engineering, Kozaračka 2a, 24000 Subotica, Serbia E-mail: igor.jokanovic.bg@gmail.com

Bojan Matić, PhD, Assist. Prof. University of Novi Sad,

Faculty of Technical Sciences, Trg Dositeja Obradovića 6, 21000 Novi Sad, Serbia E-mail: bojan.matich@gmail.com

Miloš Šešlija, MSc, Assistant, PhD candidate

University of Novi Sad,

Faculty of Technical Sciences,

Trg Dositeja Obradovića 6, 21000 Novi Sad, Serbia

E-mail: sele@uns.ac.rs 